\title{
Chapter 12 \\ Ethical Issues in Genetics (Premarital \\ Counseling, Genetic Testing, Genetic \\ Engineering, Cloning and Stem Cell \\ Therapy, DNA Fingerprinting)
}

\section{The Progeny-Islamic Views}

The main relevant ethical aspects related to care for the family unit in Islam can be summarized as follows:

1. To ensure appropriate selection of the members of the "legal marriage" and to care for offspring throughout his or her life-preconception, prenatal, postnatal - and thereafter to ensure, as much as possible, a "stable marriage and healthy offspring."

2. Islam requires husband and wife to take necessary steps to protect themselves and their offspring, through the prevention of ill health and take appropriate steps to ensure their health as well as the health of their children at various stages of life.

3. To make use of "Advancement of Science" and seek means of protection from disease(s), including early diagnosis and intervention to ensure, as much as possible, freedom from ill health [1].

The Prophet (PBUH), more than fourteen centuries ago, had highlighted the importance of "selection of compatible couples" and indicated inheritance in children. The effect of genetic inheritance was also indicated by "Hadith" of the Prophet (PBUH) related to the "man" who came to the Prophet (PBUH) complaining that his wife gave birth to a black child. The Prophet asked him: "If he has camels?" The man answered: "Yes." The Prophet (PBUH) asked him: "What is their color?" The man said: "They are red." The Prophet (PBUH) asked him: "Is there any blackish (grey) among them?" The man answered: "Yes." The Prophet (PBUH) asked him: "Why do you think that is?" The man said: "This may be due to unseen 'Erg' (inheritance). The Prophet (PBUH) said: "your son has the same" [2]. 


\section{Genetic Disorders}

A genetic disorder is an illness caused by abnormalities in genes or chromosomes, while some diseases, such as cancer, are due in part to a genetic disorders, they can also be caused by environmental factors. Except for genetic blood disorders like sickle cell anemia and thalassemia, and cystic fibrosis (in certain geographic location), most disorders are rare and affect one person in every several thousands. Chromosomal defects constitute a large number of early abortions. Both chromosomal and genetic defects are responsible for major part of late abortion, stillbirth and perinatal death. They also constitute an important part of early childhood diseases. Some cancers, e.g., polyposis coli are autosomal dominant.

In fact, nearly all diseases have a genetic component. Some, including many cancers, are caused by a mutation in a gene or group of genes in the cells of an individual. Such mutations can occur randomly or due to some environmental exposure (such as cigarette smoking).

Other genetic disorders are hereditary — such as Huntington disease or Marfan's disease-where a mutated gene is passed down through a family and each generation of children can inherit the gene that causes the disease.

But most genetic disorders are "multifactorial inheritance disorders," meaning they are caused by a combination of small variations in genes, often in concert with environmental factors.

$\underline{\text { Genetic disorders are classified into three categories }}$

1. Single gene disorder: is the result of a single mutated gene and inherited as autosomal recessive, autosomal dominant, and x-linked. The mutation may be present on one or both chromosomes (one chromosome inherited from each parent). Sickle cell disease, and cystic fibrosis are examples of single gene disorders.

2. Chromosome disorders caused by an excess or deficiency of the genes that are located on chromosomes, or structural changes within chromosomes. Down syndrome, for example, is caused by an extra copy of chromosome 21 .

3. Multifactorial inheritance disorders caused by a combination of small variations in genes, often in concert with environmental factors. Heart disease and most cancers are examples of these disorders.

\section{Genetic and Congenital Disorders in Islamic World}

Genetic and congenital disorders are more common in Arab countries than in industrialized countries. The incidence of congenital malformations and genetic disorders in Gulf countries amounts to $7.3 \%$ of births, compared to the average of $4.4 \%$ in Europe. In Saudi Arabia, the sickle cell gene and B-thalassemia occur at a 
rate of 1-20\% according to different regions, with 2000 affected newborns added to the pool annually [3].

Congenital and genetic disorders are responsible for a major proportion of infant mortality, morbidity, and handicap in Arab countries. The population of the region is characterized by large family size, high maternal and paternal age, and a high level of inbreeding with consanguinity rates in the range of 25-60\% [4].

Several factors may contribute to the high prevalence of genetically determined disorders:

- High consanguinity rates - 25 to $60 \%$ of all marriages are consanguineous, and the rate of first cousin marriages is high.

- The high prevalence of hamoglobinopathies, glucose-6-phosphate dehydrogenase deficiency, autosomal recessive syndromes, and several metabolic disorders.

- The rate of children with Down's syndrome in some Arab countries exceeds the 1.2-1.7 per 1000 typical for industrialized countries. This may be related to the relatively high proportion of births to older mothers in the region (up to $50 \%$ of children with Down's syndrome in the region are estimated to be born to mothers aged 40 or over). In the west, prenatal diagnosis of Down syndrome ends in abortion in most cases.

- The lack of public health measures directed at the prevention of congenital and genetic disorders, with inadequate health care before and during pregnancy, particularly in low income countries.

- Services for the prevention and control of genetic disorders are restricted by certain cultural, legal, and religious limitations [5].

In the United Kingdom there are more than 250,000 people from the Middle East, among whom an estimated 3000 births occur each year [6]. Germany, Sweden, and the Netherlands have similar populations. Healthcare professionals in the West may assume that Muslim families will not consider termination of pregnancy, but this may not be the case. Families must be offered a full explanation of the risks they face and the range of interventions available to them [7]. People who have left their country of origin tend to preserve their original beliefs and cultural values [8].

\section{Consanguinity}

A consanguineous marriage is usually defined as marriage between people who are second cousins or closer. Incest is sexual intercourse between family members and very close relatives. Father-daughter marriage or sisters and brothers marriages are not allowed. All cultures and religions consider such a relation as a taboo. However it is well known that the Pharoes and the old Persians allowed marriage between brothers and sisters. In the old testament (book of Genesis) it is claimed that Abraham married his half sister Sarah [9], while "Lot" had sex with his two 
daughters and both of them became pregnant of that incest and delivered Moab and Benammi [10]. Islamic teachings refute such claims and consider the messengers of God as the purest persons on earth, and will never do such horrendous acts.

Consanguineous marriage is known to have many social and economic benefits, although Islamic teachings discourage it [11]. Omer Ibn Al-Khatab, the second khalifa, noticed that the progeny of the tribe of Bani Alsaa'b had become weak and unhealthy because of intermarriage of cousins. He advised the tribe to avoid close cousin intermarriage and to seek wives and husbands from tribes further afield, cautioning: "Marry from faraway tribes; otherwise you will be weak and unhealthy" [12].

It is estimated that $20 \%$ of human population live in communities with preference for consanguineous marriage, and at least $8.5 \%$ of children have consanguineous parents [13]. Consanguineous unions account for 20-70\% of all marriages in the Middle East, excluding Israel and Cyprus [14].

Studies of parental consanguinity in the general population in Egypt throughout the last 40 years showed an average consanguinity rate above $30 \%$. Parental consanguinity rates in groups of Egyptian patients with various birth defects are significantly higher than that of the general population according to the most recent estimate $(33 \%)$ [15].

This frequency of consanguinity leads to increased birth prevalence of infants with severe recessive disorders but has a relatively small effect on the prevalence of dominant and X-linked disorders, and its role in complex disorders is still uncertain.

Generally speaking, frequency of congenital and genetic diseases among newborns of first cousin unions is about 2 times the frequency among the general population. In other words instead of a rate of 2-3\% of birth defects in the general population, the risk to first cousin couples is around 4-6\%. Another estimate puts the offspring of first cousin unions at a 1.7-2.8\% increased risk above the population background risk [16]. The highest risks are from first degree marriage viz.: Parent child and sib to sib where they share half the genetic pool.

However, when the autosomal recessive gene in the community is very common namely Thalassemia, and sickle cell anemia, the carriers of the trait are one in 4 , or one in 5 in the whole community, any marriage will have a high risk of marrying another carrier of the trait [17].

\section{Genetic Disorders: A Community Hurdle in Islamic Communities}

Genetic disorders occur at a high frequency in several Islamic communities.

The blood genetic disorders cause a variety of negative effects on health and psychosocial aspects due to the following: (1) Its wide spread in the community. (2) Chronicity and nonavailability of definitive treatment, and (3) Negative effect on the life style of the concerned individual, family, and the community at large. 
Genetic diseases due to their chronic nature impose heavy medical, financial and emotional burdens. Therefore, the efforts to combat these problems are multifaceted and the effective control and prevention strategies gain a high priority beside care and rehabilitation of the affected in the community [18].

The whole family suffers from the daily strain of observing and caring for the affected individuals. It is notable that mothers with one affected child would be stressed; a mother with 2 or 3 affected children may become psychologically disturbed or depressed. Fathers are weary, visiting many hospitals, searching for someone who can offer treatment, or explain to them how to deal with the affected children better. In addition, financial difficulties often arise, especially in families with multiple affected children.

The responses from the concerned family to a genetic disease are associated with feelings of fear, misfortune, shame, guilt, anger, isolation, and blame and are accentuated by negative notions in the mass media, and unavailability of a definitive cure in most conditions. An increasing number of couples now seek premarital information on the risk of having genetically affected children [19]. Therefore, genetic services for patient care and control and prevention measures are necessary to:

- Help people with genetic disadvantage and their families,

- Live and reproduce as normally as possible,

- Make informed choices in reproductive and health matters,

- Assist people to obtain access to relevant medical services (diagnostic, therapeutic, rehabilitative, or preventive) and social support systems,

- Help affected people adapt to their unique situation, and

- Help affected people become informed on relevant new developments [20].

\section{Premarital Examination Program}

The main objectives of the premarital examination can be summarized as follows: (1) To limit the occurrence of genetic disorders. (2) To limit those marriages among those who are carriers or suffering from blood genetic disorders. (3) Explaining the pattern of inheritance of genetic disorders. (4) Save the families from having affected children suffering from a chronic disease and psychosocial problems. (5) Minimizing the economic burden on the family and on the government that results from seeking treatment for chronic and disabling genetic disorders [21].

Reassurance for carriers is important. The explanation should be given that to be a carrier is not an illness and not a God's punishment. Being a carrier is not shameful and is often associated with advantage for survival. In the case of sickle cell disease, carrier is selected by nature for survival against malaria. A carrier will have resistance to the illness later on. The advantage of knowing one is a carrier is to be able to plan a healthy family and avoid genetic disease. Any carrier can marry a non carrier of that gene. 


\section{Responses in the Arab World}

Many Arab governments (Saudi Arabia, Egypt, Syria, Lebanon, Tunisia, Morocco, and Gulf countries) made a premarital medical examination mandatory. It resulted in some reduction of autosomal recessive blood disease (viz thalassemia and sickle cell anemia).

The premarital test for sickle cell, thalassemia and G6PD became compulsory. If both are carriers, they are counseled and advised against marriage, but the decision is theirs.

\section{Genetic Testing}

As currently practiced, genetic testing occurs at one of six stages in the life cycle:

(1) Premarital Genetic Diagnosis (Vide Supra); (2) during the neonatal period; (3) prenatally, that is, between implantation and birth; (4) during the preimplantation stage of embryonic development, following in vitro fertilization; (5) when couples are considering whether to reproduce; or (6) when a person, often on the basis of family history, recognizes a higher-than-average risk of developing a particular disease later in life, for example, Huntington disease or breast cancer.

Genetic testing and screening raise some of the most difficult issues in the entire field of bioethics. On the one hand, it is clearly beneficial to reduce the incidence of severe disease, especially among children. In addition, individuals and couples can exercise their autonomy by deciding whether, when, and under what circumstances they will try to have children. And societies can focus their resources on people whose illnesses cannot be prevented and on people who are injured in accidents. On the other hand, deliberations about prenatal diagnosis and selective abortion are often agonizing for the people involved [22].

\section{Genetic Counseling}

Genetic counseling is the process whereby an individual or family obtains advice and information about a genetic condition that may affect the individual and family. The aim of such counseling is to enable appropriate decisions to be taken regarding marriage, reproduction, abortion, and health management. It is considered an important complementary approach to the screening procedure. As a service, it is offered to the members of the high risk groups, i.e., carriers of recessive genetic disease or those with an affected member of the family.

The principles and components of the "Informed Consent" that are generally acceptable in western countries are also applicable to Muslim community. 
However, Muslims, in general, will often want to consult with family members and religious scholars, particularly in aspects of religious and social relevance [23].

Families with handicapped children should not be blamed, criticized, but should be supported in all ways possible. Health practitioners need to adopt a sensitive approach in providing health information paying attention to their vocabulary to ensure that unintended meanings are not communicated.

Every effort should be made to minimize diagnostic uncertainty [24].

\section{Qualifications and Task of the Counselor}

The counselor should be trustworthy, proficient, considerate, compassionate, and able to guard the confidentiality of the information he is given. The genetic counselor may not impose his views on his clients. Rather, he must let them reach their own decisions. The counselor's responsibility is to provide them with the necessary facts and information in plain language that they can understand easily and fully [25]. There are 3 main reasons why an appropriate counseling approach is essential: (1) Psychological, social, and ethical problems can arise as the result of genetic testing; (2) Genetic tests have high predictive values, thus can exclude or identify particular risks; (3) Currently, a large gap exists between the ability to diagnose, and the ability to treat genetic diseases.

Premarital carrier detection is important especially in communities where consanguinity is very high. If the fiancé and fiancée are found carrying the same autosomal recessive gene, then genetic counseling should be provided, and all the pertinent facts and risks to the progeny explained. If they insist on marriage, the decision is theirs, but reproductive alternatives should be discussed with them.

They should be counseled to choose a number of alternatives, should they still wish to marry.

\section{Other Options}

1. Contraception or sterilization to avoid pregnancy;

2. Adoption;

3. Donation of a sperm or ovum or pre-embryo;

4. Preimplantation diagnosis;

5. Diagnosis during pregnancy (e.g., chorion villus sampling, amniocentesis, blood tests from the expectant mother and the fetus, ultrasonography, etc.).

Each of these procedures needs to be scrutinized from an Islamic perspective: 


\section{Contraception and sterilization}

Contraception is allowable under Islamic law as a temporary measure if the couple decide upon it and if there is no harm from the particular method used. Sterilization, however, is not acceptable unless there is danger to the mother's health from pregnancy. We may note that there is support for sterilization from at least some of our jurists in the situation where a couple have already had some congenitally affected children.

\section{Adoption}

Adoption was abrogated by the Qur'an, and in Islamic law adoptive parents are not recognized as parents in the way that natural parents are. The child must be attached in lineage to his or her natural parents, and legitimate pregnancy is, according to the law, only within wedlock. The Qur'an says: "He did not make your adopted ones your sons [26]. Bringing up orphans is a highly commended act of charity, encouraged by Islamic teachings, but even then the lineage of the child must remain to his or her natural parents."

\section{Donation of a sperm, ovum or pre-embryo}

In the West, a new technology of procreation is being made available to infertile couples. This technology, making use of semen banks and in vitro fertilization techniques, may involve donated sperm or ova; a donated pre-embryo (blastula or morulla). None of this technology is acceptable in the view of Islamic teachings which recognize procreation only within the bounds of wedlock excluding any third party from the process. Therefore, a Muslim couple who are carrying a lethal gene or serious disease gene cannot make use of either donated sperm or ova or preembryos. These methods are refuted by all Islamic jurists on the grounds that procreation must be limited to the spouses alone, without the intervention of third parties during the existence of matrimonial bondage. If divorce or death of a spouse occurs no procreation will be allowed.

\section{Preimplantation genetic diagnosis (PGD)}

Advances in medical technology over the last few decades have made it possible, at least in some specialist clinics, to remove one or more cells from the blastula (preembryo) prior to its implantation in the womb. A husband's semen is allowed to fertilize in vitro the ovum taken from his wife; when fertilization occurs, the zygote is allowed to grow to the blastula or morulla stage - this happens a few days after fertilization. If genetic disease or chromosomal abnormality (e.g., triosomy 13, 18 or 21) is suspected, one or more cells are taken from the blastula for appropriate testing. If the blastula is shown to have the defective gene or chromosome, it is discarded and another one tested. Only the unblemished blastula is reimplanted.

PGD technology was made possible through the use of microinjection of an oocyte with a single spermatozoon as in intracytoplasmic sperm injection (ICSI) technique and the micromanipulation of the resulting embryo. Moreover, the technology involves removing 1-2 cells from each of the 6-8 cell stage embryos (usually 3 days 
after the ICSI procedure), studying each cell for chromosomal anomalies or screening for certain single-gene defects. Normal embryos are then transferred into the uterus while unwanted ones are discarded or used for research [27].

Although PGD screening has been available for nearly three decades in Western Europe currently, PGD is used mainly in two broad indication groups. The first group consists of individuals at high risk of having a child with a genetic disease, for example carriers of a monogenic disease or of chromosomal structural abnormalities such as translocations. The second group consists of those being treated with IVF, who might have a low genetic risk but whose embryos are screened for chromosome aneuploidies to enhance their chances of an ongoing pregnancy [28].

PGD is permissible in Islam provided the sperms and oocytes are from the husband and wife. PGD may be preferable to prenatal diagnosis for Muslim parents, because it is done when pre-embryos are only at the eight-cell stage and may avoid abortion. It is not an easy option, and couples must be selected and counselled appropriately [29].

PGD services in the Middle East is not available except in few centers. In summary, the procedure is still in its early stages, with many limitations.

\section{Prenatal screening and diagnosis of genetic disorders}

Better and more accurate diagnoses of congenital malformations, genetic diseases and chromosomal abnormalities are becoming available with the tremendous advances in medical technology. This will involve blood testing of the mother for alpha fetoproteins, gonadotrophins, and more recently for fetal cells.

Simple blood tests from the expectant mother can help the diagnosis of, for example, alpha fetoproteins in cases of neural tube defects, viz., anencephaly and spina bifida. Ultrasound can detect many dysmorphic abnormalities as well as congenital defects of the heart, brain anencephaly, and spina bifida and kidneys.

Chorion villous sampling (CVS) is carried out in the 9-10th week from last menstrual period of pregnancy and if the fetus is proved suffering from serious congenital anomaly then abortion is offered. If CVS was not available, then ultrasound study, amnniocentesis and blood sampling from the fetus will confirm the diagnosis. If the congenital anomaly is very serious, abortion could be carried, provided it is carried out prior to the 120 days from conception (134 days from last menstrual period).

Amniocentesis is done at a much later stage of pregnancy, between the 14 and 16th weeks. The advantage of early diagnosis by CVS is offset by higher percentage of abortions and complications (2-3\%), compared to amniocentesis which is safer albeit giving a much later diagnosis.

Prenatal screening and diagnosis of genetic disorders serves two purposes. First, it identifies fetuses that are affected with a disorder. Parents may then choose to terminate the pregnancy or, if they opt to continue the pregnancy be assisted with the management of a high risk pregnancy, be prepared for the birth with appropriate family and social support, and receive a modified delivery plan appropriate for the disorder. Second, for those with unaffected pregnancies, parents receive reassurance [30]. 
Screening tests have been primarily targeted towards the identification of two types of fetal disorders:

1. Chromosome abnormalities, notably Down syndrome, identified through the combination of maternal age, maternal serum biochemical tests, and fetal ultrasound; the definitive diagnosis is through CVS or amniocentesis.

2. Single gene disorders with Mendelian patterns of inheritance screened through carrier testing of parents (e.g., cystic fibrosis, hemoglobinopathies, neurodegenerative disorders, or other conditions that have a high prevalence in particular racial or ethnic groups).

Depending on the population screened and the test protocols, only a proportion of the affected pregnancies are identified as high risk. Screening protocols can be relatively expensive. Furthermore, women with positive-screening results require a definitive diagnosis through amniocentesis or chorionic villus samples (CVS). These "invasive tests" carry a small risk for miscarriage and maternal complications.

They are also expensive, anxiety provoking and likely to be completed relatively late in pregnancy [31].

\section{Islamic Teachings and Prevention of Genetic Diseases}

Islamic teachings concentrate on prevention of disease rather than cure. Islam encourages marriage and prohibits fornication and adultery.

The Prophet Muhammad (PBUH) advised Muslims to choose for their daughters, husbands with good character and free from physical and social illnesses. Similarly he warned not to marry a girl only for her beauty when her character is blemished [32]. He also said: "Choose for your offspring the suitable woman for hereditary plays a role" [33].

The premarital examination to avoid genetic diseases will be a welcome; especially in a community where the rate of consanguineous marriage is high [34]. These practices are carried out in a number of Islamic Countries and considered the method of choice in prevention of Single Gene Disorders. Congenital diseases such as Rubella are virtually eliminated in many countries by vaccinating school children girls at premarital age. Syphilis and other sexually transmitted diseases (STD) will not appear if all sexual desires are channeled through marriage as Islamic teachings implies. Fornication, adultery, and sodomy are all harshly punished in Islamic legal code, and religiously they are considered of the greatest sins, that each Muslim should avoid. Alcohol is the most frequent chemical teratogen substance causing mental retardation and congenital anomaly. Islam totally prohibits imbibing alcoholic beverages. Similarly smoking causes abortion, congenital anomalies and small for date babies. It is prohibited in Islamic teachings and many fatwas have reiterated its prohibition. Any substance that is going to be harmful to the baby (namely teratogen) should be avoided as the Prophet Muhammad (PBUH) him said: "Do no harm" [35]. 
Similarly, neonatal testing, avoiding of teratogens and provision of folate and iodine in the diet is encouraged as supportive measures. Simple tests for phenylketonuria, homocystinuria, galactosemia and many others for newborns can avert calamity in those affected.

\section{Abortion for Genetic Diseases}

The "Fatwa" number 4 of "Islamic Fiqh council of Islamic World League, Makkah Al Mukaramah," at its 12th session (Makkah, 10-17 February 1990) allows for the option of abortion under certain specific conditions. The fatwa determined that the abortion may take place only if a committee of specialized, competent physicians has decided the fetus is grossly malformed, and that its life would be a calamity for both the family and itself. The malformation must be untreatable, unmanageable and very serious, and the abortion may only be carried out prior to the 120th day of conception (computed from the date of fertilization, not the last menstrual cycle). Beyond 120 days, i.e., after the ensoulment, abortion only is allowed if there is a danger threatening the mothers' life and not only her health [36]. This Fatwa was a landmark, as previous Fatwas only allowed abortion in the first 40 days of conception. At such a period it was almost impossible to ascertain any of the congenital or hereditary diseases. By extending the time of permissible abortion to 120 days computed from the moment of conception (namely 134 days from LMP), gives ample time to ascertain the diagnosis of severely affected embryo's and fetuses. Abortion is one of the reproductive options offered to manage and prevent genetic diseases.

On the basis of this fatwa, abortions of fetuses with serious congenital diseases are carried out in the hospitals in Saudi Arabia.

\section{Genetic Engineering}

Genetic engineering is the direct manipulation of an organism's genome using biotechnology. Genetic engineering alters the genetic makeup of an organism using techniques that remove heritable material or that introduces DNA prepared outside the organism either directly into the host or into a cell that is then fused or hybridized with the host.

In medicine, genetic engineering has been used to mass-produce insulin, human growth hormones, other hormones for treating infertility, human albumin, monoclonal antibodies, antihemophilic factors, vaccines, and many other drugs.

Genetic engineering is used to create animal models of human diseases. Genetically modified mice are the most common genetically engineered animal model. They have been used to study and model cancer, obesity, heart disease, diabetes, arthritis, substance abuse, anxiety, aging, and Parkinson disease [37]. 
Potential cures can be tested against these mouse models. Also, genetically modified pigs have been bred with the aim of increasing the success of pig to human organ transplantation, but the occurrence of many porcine retroviruses hampered the whole project.

\section{Gene Therapy}

Gene therapy is the genetic engineering of humans by replacing defective human genes with functional copies. It derives its name from the idea that DNA can be used to supplement or alter genes within an individual's cells as a therapy to treat disease. The most common form of gene therapy involves using DNA that encodes a functional, therapeutic gene to replace a mutated gene. Other forms involve directly correcting a mutation, or using DNA that encodes a therapeutic protein drug (rather than a natural human gene) to provide treatment.

Gene therapy utilizes the delivery of DNA into cells, which can be accomplished by a number of methods. The two major classes of methods are those that use recombinant viruses (sometimes called biological nanoparticles or viral vectors) and those that use naked DNA or DNA complexes (nonviral methods).

Gene therapy has been used to treat patients suffering from immune deficiencies (notably Severe combined immunodeficiency) and trials have been carried out on other genetic disorders. The success of gene therapy so far has been limited and a patient (Jesse Gelsinger) has died during a clinical trial testing a new treatment [38]. There are also ethical concerns should the technology be used not just for treatment, but for enhancement, modification or alteration of a human being appearance, adaptability, intelligence, character, or behavior. The distinction between cure and enhancement can also be difficult to establish.

Gene therapy may be classified into the two following types:

- Somatic gene therapy

In somatic gene therapy, the therapeutic genes are transferred into the somatic cell, or body, of a patient. Any modifications and effects will be restricted to the individual patient only, and will not be inherited by the patient's offspring or later generations. Somatic gene therapy represents the mainstream line of current basic and clinical research.

- Germ line gene therapy

In germ line gene therapy, germ cells, i.e., sperm or eggs are modified by the introduction of functional genes, which are integrated into their genomes. This would allow the therapy to be heritable and passed on to later generations. Although this should, in theory, be highly effective in counteracting genetic disorders and hereditary diseases, many jurisdictions prohibit this for application in human beings, at least for the present, for a variety of technical and ethical reasons. In summary, the attention of researchers and bioethicists is now focused primarily on experimental approaches to the treatment of individual patients 
suffering from either debilitating or lethal diseases. Unlike the situation in the late 1960s and early 1970s, germ-line intervention and the enhancement of human capabilities by genetic means are not the principal topics of debate. One hopes that in the future, gene transfer will join bone marrow transplantation, solid organ transplantation, and, perhaps, stem-cell transplantation as an effective therapeutic modality for an increasing number of human maladies [39].

\section{Islamic Position on Genetic Engineering}

The Islamic Fiqh council of Islamic World League, Makkah Al Mukaramah, in its 15th session (11th/07/1419Hijra/31 October 1998 Gregorian) gave the following guidance on the use of the genetic information and research technology:

1. Allow the use of genetic engineering for disease prevention, treatment, or amelioration on the condition that do not cause further damage;

2. Forbid the use of engineering in evil and criminal use or what is forbidden religiously;

3. Forbid using genetic engineering and its tool to change human personality and responsibility, or interfering with genes to improve the human race;

4. Forbid any research or therapy of human genes except in extreme need, after critical evaluation of its benefits and dangers and after an official consent of the concerned, respecting the extreme confidentiality of the information and human rights and dignity as dictated by Islamic Shari'ah;

5. Allow the use of bio-engineering in the field of agriculture and animals, on the condition that precautions are taken not to inflict harm (even in the long term) on humans, animals or vegetation;

6. Call on biotechnology companies and food and medical factories to reveal the structure of these bioengineered products so they can be dealt with and used with caution in light of potential harm or if any are forbidden religiously;

7. Recommend all doctors, factory and laboratory owners to fear Allah (God) and to watch out for Allah to avoid inflicting harm to humans, society or the environment [40].

\section{Cloning and Stem Cell Research}

Human cloning is the creation of a genetically identical copy of a human. The sheep Dolly (5 July 1996-14 February 2003), was the first mammal to have been successfully cloned from an adult cell.

To make Dolly, researchers isolated a somatic cell from an adult female sheep. Next, they transferred the nucleus from that cell to an egg cell from which the nucleus had been removed. After a couple of chemical tweaks, the egg cell, with 
its new nucleus, was behaving just like a freshly fertilized zygote. It developed into an embryo, which was implanted into a surrogate mother and carried to term.

The lamb, Dolly, was an exact genetic replica of the adult female sheep that donated the somatic cell nucleus to the egg. She was the first-ever mammal to be cloned from an adult somatic cell.

There are two commonly discussed types of human cloning: therapeutic cloning and reproductive cloning. Therapeutic cloning involves cloning cells from an adult for use in medicine and transplants, and is an active area of research. Reproductive cloning would involve making cloned humans, for couples wanting to have a child, but cannot naturally.

- Therapeutic cloning

In this technique a somatic cell, e.g., a skin cell is fused with an enucleated ovum. The fused cell is then induced to divide and form a blastocyst. Stem cells are then harvested from the inner cell mass of this cloned embryo. It has the same DNA as the original somatic cell. This process termed Somatic Cell Nuclear Transfer (SCNT) holds great promise for regenerative medicine [41]. The applications of this technique are still in the realm of expectations.

Muslim jurists have different views. SCNT raises many moral objections in addition to what will discussed in relation to hESC research. The cloned embryos will be produced exclusively for research, unlike other Human Embryonic Stem Cells (hESC) research that is utilizing 'spare' pre-embryos at IVF clinics [42].

\section{Islamic Position on Cloning}

Cloning is indeed a most serious issue as it is a reversion to the most primitive form, asexual reproduction. It conflicts with the Qur'anic verse: “God created consorts for you from amongst you and through them. He gave you children and grandchildren. Do they then believe in vain things and deny the blessing of God?" [43]. The bleak prospects of cloning are already manifested by the very high rate of fetal wastage before a clone is born [44].

In addition to the fact that a resulting embryo from reproductive cloning would be severely deformed with developmental abnormalities and early aging, the major problems of reproductive cloning are:

(1) the loss of kinship and lineage due to the unnaturalness of reproduction (mixing of kinship or the loss of it, would be considered haram) (unlawful in Isalm) and undermining the concept of reproduction and family (Holy Qur'an 4:1)

(2) the social harms, problems of personal identity and the psychological development of a clone and the disregard for human dignity

(3) the unjust eugenics (selecting genetic qualities by selective breeding) and trends towards "designer babies" (superior or inferior, depending upon the motives of the creator)

(4) the contradiction of the Islamic belief (God is the only and the best creator) 
(5) the contradiction of the principle of creation of all beings (human, animal, plants) in pairs (male and female). However, as cloning produces the exact copy of the previously existent individual whether male or female, this leads to a disturbance of the natural existence of pairs, and finally

(6) the contradiction of the principle of diversity of creation of all beings, including human, animals, and plants in various colors and shapes [45].

Therefore, human cloning is forbidden in any method that leads to human reproduction.

The International Islamic Fiqh Academy of Organization of Islamic Conferences (OIC-IFA) in Jeddah in its 10th session (23-28. 2.1418H/28 June-3 July 1997 CE) explored all the research papers and recommendations of the 9th Medical \& Fiqh Seminar held by the Islamic Medical Organization in Casablanca, Morocco, in collaboration with the Council and others (14-17 June 1997 CE), and declared Decree \#100/2/D10:

1. Human Cloning is forbidden in any method that leads to human reproduction.

2. It is forbidden in all cases to introduce a third party into marriage, be it an egg donor, a surrogate womb, a sperm donor, or a cloned cell.

3. It is permissible to use genetic engineering and cloning in the fields of germs, microorganisms, plants, and animals, following legitimate rules which lead to benefits and prevent harm.

4. All Muslim countries are called upon to formulate the necessary legislation to prevent foreign research institutes, organizations and experts from directly or indirectly using Muslim countries for experimentation on human cloning or promoting it.

5. Specialized committees should be set up to look into the ethics of biological research and adopt protocols for study and research in Muslim countries.

6. Biological and bioengineering research institutions (other than cloning research) should be supported and established, according to the Islamic rulings, so that the Muslim World will not be dependent on others in this field.

7. The mass media are called upon to deal with recent scientific advances from an Islamic perspective in a faithful way and avoid employing their services against Islam, aiming to educate the public to be confident before any decision.

$\underline{\text { Stem cell research }}$

Stem cell research is a very promising new field of medicine. It potentially holds the promise of a cure for many so far incurable diseases like Alzheimer's, genetic diseases, and malignancies.

The embryonic stem cells (ESCs) are the original cells from which all the 220 different types of cells that compose the human body develop.

Stem cells are also present in adult tissues in small numbers. Their ability to trans differentiate into cells of another lineage is very limited compared with that of ESCs. There is probably one exception, umbilical cord blood stem cells (UCB) SCs. Stem cells can be procured from fertilized eggs in storage following in vitro fertilization, but also are found in the placenta, umbilical cord and the blood in the 
normal human circulatory system. Up to now, the most readily available source seems to be the surplus fertilized ova left over after in vitro fertilization [46]. Cord blood is more readily available.

The ESC research is morally controversial because it involves sometimes the deliberate production, use and ultimate destruction of human pre-embryos.

To obtain hESCs one has to destroy a 5-7-day-old pre-embryo. The crux of this conflict is the question whether the 5-7-day-old pre-embryo is a human being entitled to protection against harm or destruction [47]. (The Catholic view and its supporters).

One side of the debate raises the dictum of the "sanctity of human life." From an Islamic point of view, we have already alluded to the inviolability of human life from the point of implantation onwards. A fertilized ovum in storage does not, however, possess the same rights as a fetus and it may be used if the purpose is to protect and save human life. Our argument rests on the following points:

- The Arabic word for embryo and fetus is "Janin" which means a conceptus hidden in the womb. If it is not in uterus, then it is not a "janin", i.e., not embryo nor fetus.

- If kept in storage, the fertilized ovum will acquire genetic anomalies and will, sooner or later, die.

- It is not part of the feto-maternal unit of a pregnancy.

- A somatic cell, such as a skin cell, can be made into an embryo through the process of cloning and yet, nobody ever claimed sanctity for skin cells.

- According to Islamic teaching, a fertilized egg, not yet residing in the mother's uterus, does not have the spirit instilled into it [48]. The ensoulement occurs at 120 days after fertilization.

On the basis of the concept that definitive human life does not start until ensoulment the great majority of Muslim scholars agree that research on the preembryo, especially the preimplantation pre-embryo - as it cannot grow independently outside the uterus - is permissible, provided that these pre-embryos were legitimately developed. The permissibility is also conditioned on the fact that these embryos are not produced specifically for research. Supernumerary embryos produced at infertility clinics are considered legitimate [49]. The surplus fertilized ova should be donated by the spouses who produced it.

\section{Islamic Position on Stem Cells Research}

In the opinion of most Muslim jurists, stem cell and cloning research, as scientific advancement, would have advantages and limitations.

While the majority of Islamic jurors permit Human Embryonic Stem Cells (hESC) research, all agree that that creating embryos for the sole purpose of research is prohibited.

Stem cell therapy is allowed if the source of the cells is legitimate including left over zygotes, and if the parents have consented to its use. Similarly spontaneous abortion or medically indicated abortion can be used as a source of Stem cells if the parents agree. 
The practical application of the use of stem cells in therapy is the use of bone marrow transplant to treat blood disorders like thalassemia and leukemia and it is used to treat certain storage disorders. Umbilical cord blood banks are available in the Kingdom of Saudi Arabia and the UAE [50]. Because of the inevitable consequences of reproductive cloning; it is prohibited by the majority of Muslim reference decrees. However, stem cell research for therapeutic purposes is permissible with full consideration and all possible precautions in the pre-ensoulment stages of early fetus development.

The Islamic Fiqh council of Islamic World League, Makkah Al Mukaramah in its 17th session (19-23.10.1424 H/13-17 December 2003 CE) have declared Decree \#3 on Stem Cell Therapy:

First: It is permissible to obtain stem cells, to be grown and used for therapy or for permissible scientific research, if its source is legitimate, as for example:

1. Adults if they give permission, without inflicting harm on them.

2. Children provided that their guardians allow it, for a legal benefit and without inflicting harm on the children.

3. The placenta or the umbilical cord, with the parents' permission.

4. A fetus if spontaneously aborted or when aborted for a therapeutic reason permitted by Shari'ah, with the parents' permission (Be reminded of Decree \#7 of the Council in its 12th session about abortion).

5. Leftover zygotes remaining from in vitro fertilization, if donated by the parents, when it is ascertained that they will not be used in an illegal pregnancy.

Second: It is forbidden to use stem cells, if their source is illegal. As for example:

1. Intentionally aborted fetuses (that is, abortion without a legal medical reason).

2. Intentional fertilization between a donated ovum and sperm.

3. Therapeutic human cloning.

The Fiqh Council of North America in 2007 affirmed its earlier position of support for hESC research [51]. The Islamic Medical Association of North America (IMANA) Ethics Committee published a position paper on SC research and added its approval [52]. Both the Islamic Institute of Turkey and the Malaysian National Fatwa Council also supported hESC research [53].

\section{DNA Fingerprinting}

DNA fingerprinting, also called DNA typing, in genetics, method of isolating and making images of sequences of DNA (deoxyribonucleic acid). The technique was developed in 1984 by the British geneticist Alec Jeffreys, after he noticed the existence of certain sequences of DNA (called minisatellites) that do not contribute to the function of a gene but are repeated within the gene and in other genes of a DNA sample. Jeffreys also determined that each organism has a unique pattern of these minisatellites, the only exception being multiple individuals from a single zygote (e.g., identical twins) [54]. 
DNA profiling is employed by forensic scientists to assist in the identification of individuals by their respective DNA profiles. DNA profiles are encrypted sets of numbers that reflect a person's DNA makeup, which can also be used as the person's identifier. It is used in, for example, parental testing and criminal investigation.

A sample of blood, saliva, semen, or other appropriate fluid or tissue from personal items (e.g., toothbrush, razor, etc.) is required for the test. Although $99.8 \%$ of human DNA sequences are the same in every person, enough of the DNA is different to distinguish one individual from another, unless they are monozygotic twins.

The technique was challenged, however, over concerns about sample contamination, faulty preparation procedures, and erroneous interpretation of the results. Efforts were made to improve its reliability, and today the technique has been refined through the use of more-specific techniques. DNA samples that are degraded or collected postmortem typically produce less-reliable results than do samples that are obtained from a living individual.

The procedure for creating a DNA fingerprint consists of first obtaining a sample of cells containing DNA (e.g., from skin, blood, or hair), extracting the DNA, and purifying it [55]. If only a small amount of DNA is available for fingerprinting, a polymerase chain reaction (PCR) may be used to create thousands of copies of a DNA segment.

DNA analysis is widely applied to determine genetic family relationships such as paternity, maternity, sibling ship, and other kinships.

On DNA fingerprinting, The Islamic Fiqh council of Islamic World League, Makkah Al Mukaramah, in its 16th session (21-26/10/1422 Hijra/5-10 January $2002 \mathrm{G}$ ) have issued the following guidance:

1. It is religiously allowed to use DNA fingerprinting in forensic interrogations to prove crime which has no definite penalty in Islamic law (Shari'ah) (Avoid punishment if there is any doubt, as doubt should always be used for the sake of the accused), this will lead to justice and to safety of the community, as the criminal will be punished and the innocent will be freed from guilt, which is one of the most important goals of Share'ah.

2. DNA fingerprinting may be used in lineage (genealogy) only with great caution and confidentiality as the Shari'ah rules take precedence over DNA fingerprinting.

3. It is forbidden to use DNA fingerprinting in paternity (lineage) disputes, which should not precede the oath of condemnation (the sworn allegation of adultery committed by one's spouse).

4. It is forbidden to use DNA fingerprinting to confirm or refute legally proven lineage; the state should forbid this and inflict punishment, in order to protect people's honor and to preserve their lineage.

5. It is allowed to use DNA fingerprinting in proving lineage on the following conditions;

a. In case of a dispute about unknown lineage, as mentioned by the Islamic scholars because the evidence is either absent or equivocal, and to overcome (inundate) the vagueness (suspicion); 
b. in case of a dispute over babies in hospitals and nurseries or test tube babies;

c. in case of children lost because of war, accidents or natural disasters, where their family could not be found;

d. To identify babies or prisoners of war.

6. The human genome of an individual, nation, or race should not be sold for any reason; neither should it be given because of the harm it can cause. The counsel recommends that:

a. The state to forbid DNA fingerprinting testing except on judge's orders and performed in the state laboratories; the private sector should be forbidden from doing such tests because of the great danger and harm.

b. Each state should have a committee on DNA fingerprinting tests which should include legal scholars, physicians, and administrators to supervise and approve the result of such tests.

c. There should be a precise mechanism to prevent deceit, cheating, contamination, or human error in such laboratories, so the results are compatible with reality. The accuracy of these laboratories needs to be confirmed.

d. The number of genes [56] used for a test should be sufficient, in the opinion of specialists, to overcome any doubts about the accuracy of the results.

\section{Unanswered Ethical Questions and Dilemmas}

There are many dilemmas to be answered. Is it allowable to abort a fetus showing Downs syndrome although even with this condition it is possible to live a quiet, peaceful life? If the Huntington's disease gene is detected, is an abortion justified, although the disease will not appear until age 40 or even 60 ? Is it permissible to abort those who are homozygous for sickle cell disease or thalassemia or phenyl ketonuria or homocystinuria? For the last two diseases mentioned there is a treatment, namely to avoid foods that contain phenyl alanine or methionine.

It is hoped that, in the near future, advances in gene therapy will remove the need to consider abortion in such cases. In the meantime, the best policy is to encourage couples considering marriage to have premarital medical examinations for infectious and hereditary diseases common in their community. It is also important to educate people more effectively and actively about the sequel of consanguineous marriages which, as noted earlier, are very common in most Arab countries.

In conclusion, Islamic teachings offer a great deal in the prevention and control of genetic diseases to Islamic communities, which form the majority of the population in many Asian and African countries. It is important to educate people about the dangers of consanguinity, which is very common in several Islamic countries.

Premarital examination should be encouraged which may detect the trait in those intending to get married. Postnatal exam for newly born babies can detect many diseases (inborn errors of metabolism, hypothyroidism, etc.) which can be prevented by certain diets and drugs. 
Proper counseling should be provided, the dangers explained, and the options discussed. Prenatal diagnosis and the option of abortion for serious devastating diseases (prior to 120 days from conception) will reduce the incidence of such diseases. Neonatal screening can avert havoc by simple measures namely specific diets, or certain operative measures. Avoiding teratogens and provision of folate and iodine in the diet will help in reducing congenital diseases.

Open Access This chapter is distributed under the terms of the Creative Commons Attribution Noncommercial License, which permits any noncommercial use, distribution, and reproduction in any medium, provided the original author(s) and source are credited.

\section{References}

1. El-Hazmi MAF (2009) Ethical issues on preventions and management of blood genetics disorders- Islamicviews. Hemoglobin 33(S1):S1-S6

2. Sahih AlBokhari, Sahih Muslim, Fathu AlBari, Sharieh Sahih AlBokhari, by Ibn HajarAlasqalani, Hadith No 5035, 6847 and No. 7314. He said one of the grandmothers of the child was black

3. Rajab AA, El-Hazmi MA (2007) The Gulf Cooperation Countries genetic services. Understanding individuals, families, and community needs. Saudi Med J 28(9):1321-1323

4. Al-Gazali L, Hamamy H, Al-Arrayad S (2006) Genetic disorders in the Arab world. BMJ 333 (7573):831-4

5. Ibid

6. Modell B, Darlison M, Birgens H, Cario H, Faustino P, Giordano PC, Gulbis B, Hopmeier P, Lena- Russo D, Romao L, Theodorsson E (2007) Epidemiology of haemoglobin disorders in Europe: an overview. Scand J Clin Lab Invest 67(1):39-69

7. Ibid

8. Bayoumi RA, Yardumian A (2006) Genetic disorders in the Arab world. BMJ 333:819

9. Good New Bible. The Bible societies, Collins/Fontana. Book Genesis 12:10-19

10. Good New Bible. Genesis 19:30-38

11. Albar MA (1999) Counseling about genetic disease: an Islamic perspective. Easter Med Health J 5:1129-1133

12. Al Aqeel AI (2007) Islamic ethical framework for research into and prevention of genetic diseases. Nat Genet 39(11):1293-1298

13. Modell B, Darr A (2002) Genetic counseling and customary consanguineous marriage. Nat Rev/Genet 3:225-229

14. Teebi AS, El-Shanti HI (2006) Consanguinity: implications for practice, research, and policy. Lancet 367:970-971

15. Temtamy S, Aglan M (2012) Consanguinity and genetic disorders in Egypt. Middle East J Med Genet 1(1):12-17

16. Hammay H (2012) Consanguineous marriages trends, impact on health and counseling. Geneva (Online)

17. Weatherall D (1998) Some aspects of the Hemoglobinopathies of particular relevance to Saudi Arabia and other parts of the Middle East. Saudi Med J 9:107-115

18. El-Hazmi MAF (2006) Pre-marital examination as a method of prevention from blood genetic disorders. Saudi Med J 27(9):1291-1295

19. Rajab AA. op.cit

20. El-Hazmi MAF (2009) op.cit

21. El-Hazmi MAF (2006) op.cit

22. Walters L (2012) Genetics and bioethics: How our thinking has changed since 1969. Theor Med Bioeth 33:83-95 
23. El-Hazmi MAF Genehical Aspects of Research and Medical Services in Islamic Countries Mohsen A.F. El-Hazmi www.intechopen.com

24. Al-Odaib AN, Abu-Amero KK, Ozand PT, Al-Hellani AM (2003) A new era for preventive genetic programs in the Arabian Peninsula. Saudi Med J 24(11):1168-1175

25. Albar MA. op.cit

26. The Holy Qur'an 33:4

27. Eskandarani HA (2009) Pre-implantation genetic diagnosis in the Gulf Cooperative Council countries: utilization and ethical attitudes. Hum Reprod Genet Ethics 15(2):68-74

28. Alsulaiman A, Al-Odaib A, Al-Rejjal R, Hewison J (2010) Preimplantation genetic diagnosis in Saudi Arabia: parents' experience and attitudes. Prenat Diagn 30(8):753-757

29. Ibid

30. Benn PA, Chapman AR (2010) Ethical challenges in providing noninvasive prenatal diagnosis. Curr Opin Obstet Gynecol 22(2):128-134

31. Ibid

32. Al Darqutni AO (1966) Sunan Al Darqutni, Dar Al MahasinLittiba'a, Cairo, Commented by Abdullah Hashim Yamani, Kitab al Nikah (Book of Marriage) vol 3:299 (Hadith No 196, 197, 198) and vol 3:30 (Hadith No 212, 213)

33. Al Dailamy SS (1987) Firdoos Al Hikmah, Dar Al Kitab Al Arabi, Beirut, Commented by AlZumerli FA and al-Baghdadi MM, vol 2:76 Hadith No 2110

34. Albar MA. op.cit

35. AlBukhari M, Sahih AlBukhari (1958) Cairo: Matabi Asshab (1378H)

36. The Islamic Jurisprudence Council of the Islamic World League of the Organization of Islamic Countries, 12th session 1990

37. Knockout Mice (2009) Nation Human Genome Research Institute

38. Sheryl Gay (4 July 2010). Trials are halted on a gene therapy. The New York Times

39. Walters L. op.cit

40. The Islamic Jurisprudence Council of the Islamic World League of the Organization of Islamic Countries, in its 15th session, 1998

41. Fadel HE (2012) Developments in stem cell research and therapeutic cloning: Islamic ethical positions, a review. Bioethics 26(3):128-135

42. Al-Aqeel AI (2009) Human cloning, stem cell research. An Islamic perspective. Saudi Med J 30(12): 1507-1514

43. The Holy Qur'an 16:72

44. Hathout H (2006) An Islamic perspective on human genetic and reproductive technologies. East Mediterr Health J Suppl 2:S22-8

45. Al-Aqeel AI (2009) op.cit

46. Hathout H. op.cit

47. Fadel HE. op.cit

48. Hathout H. op.cit

49. Al-Aqeel AI (2009) op.cit

50. Ibid

51. The Fiqh Council of North America. Embryonic Stem-Cell Research. http://www.fiqhcouncil. org/Articles/GeneralFiqhIssues/

52. IMANA Ethics Committee (2007) Stem cell research: the IMANA perspective. Islamic Medical Association of North America, Lombard

53. Fadel HE. op.cit

54. Encyclopedia Britannica (2013). http://global.britannica.com/EBchecked/topic/167155/DNAfingerprinting

55. Ibid

56. Genes are composed of exons and introns. Exons are templates for proteins, introns are filler, and critical for DNA fingerprinting. The genes are not used for DNA fingerprinting (Exons). Introns are used 